ANADOLU, J. of AARI

ISSN: 1300-0225 (Print)

E-ISSN: 2667-6087 (Online)

2019, 29 (2): 154-163

DOI: $10.18615 /$ anadolu.660316

\title{
Production, Trade and Future Perspective of Medicinal and Aromatic Plants in Turkey
}

\author{
$\ddot{U n a l ~ K A R I K}{ }^{1}$ \\ Murat TUNÇTÜRK ${ }^{2}$ \\ ${ }^{1}$ Aegean Agricultural Research Institute, Menemen-İmir/TURKEY \\ ${ }^{2}$ Yüzüncü Yıl University Agriculture Faculty, Department of Field Crops, Van/TURKEY \\ ${ }^{1}$ https://orcid.org/0000-0001-6707-191X $\quad{ }^{2}$ https://orcid.org/0000-0002-7995-0599 \\ * Corresponding author (Sorumlu yazar): unalkarik@gmail.com \\ Received (Geliş tarihi): 08.07.2019Ａccepted (Kabul tarihi): 15.09.2019
}

\begin{abstract}
In order to solve the problems encountered in the culture of medicinal and aromatic plants, to take the research as a whole, to organize these studies and to provide coordination among the working people and institutions, in 1990, National Research Project of Medicinal and Aromatic Plants was initiated by Republic of Turkey Ministry of Agriculture and Forestry. The main purpose of these studies is to develop the registered varieties by cultivating new plant species for the production of standard and high quality raw materials required by different industries in medicinal, aromatic and dye plants in Turkey. Research institutes located in different regions of Turkey, start by selecting the appropriate type of culture to their ecology, engages in breeding and variety development work. Improvement studies have been made more efficient by integrating with quality studies to determine the active substances in plants. As a result of these studies, 41 cultivars of medicinal and aromatic plants belong to 15 species have been registered till now. The production areas of these species are increasing every year. In 2018, 300.000 tons of medicinal and aromatic plants were produced in approximately 100.000 hectares of land. 50.000 tons of this production was exported and 265 million US dollars of revenue was generated. In the following process, it is aimed to continue the culture, breeding, cultivation and quality studies and to develop new varieties and increase the production and usage areas of these varieties. On the other hand, in order to get more shares from the world herbal medicine market which is expected to reach 5 trillion USD in 2050, it is planned to give priority to the export of processed products instead of raw material export.
\end{abstract}

Keywords: Turkey, medicinal and aromatic plants, production, trade.

\section{Türkiye’de Tıbbi ve Aromatik Bitkilerin Üretimi, Ticareti ve Gelecek Perspektifi}

ÖZ: Tıbbi ve aromatik bitki kültüründe karşılaşılan sorunları çözmek, araştırmayı bir bütün olarak ele almak, bu çalışmaları düzenlemek ve çalışan insanlar ve kurumlar arasında koordinasyonu sağlamak amacıyla 1990 yılında T.C. Tarım ve Orman Bakanlı̆̆ tarafindan Tıbbi ve Aromatik Bitkiler Ulusal Araștırma Projesi başlatılmıştır. Bu çalışmaların temel amacı, Türkiye'deki tıbbi, aromatik ve boya bitkilerinde farklı endüstrilerin ihtiyaç duyduğu standart ve kaliteli hammaddelerin üretimi için yeni bitki türleri yetiştirerek tescilli çeşitlerin geliştirilmesidir. Türkiye'nin farklı bölgelerinde bulunan araştırma enstitüleri ekolojilerine uygun kültür bitkilerini seçerek ıslah ve çeşit geliştirme çalışmalarına yapmaktadırlar. Bitkilerde aktif maddelerin belirlenmesi için kalite çalışmaları agronomi çalışmaları ile bütünleştirilerek ıslah çalışmaları daha verimli hale getirilmiştir. Bu çalışmalar sonucunda şu ana kadar 15 türe ait 41 çeşit tıbbi ve aromatik bitki çeşidi tescil edilmiştir. Bu türlerin üretim alanları her yll artmaktadır. 2018 yllında yaklaşık 100.000 hektar alanda 300.000 ton şifalı ve aromatik bitki üretilmiştir. Bu üretimin 50.000 tonu ihraç edilmiş ve 265 milyon ABD doları gelir sağlanmıştır. Bundan sonraki süreçte kültür, ıslah, yetiştirme ve kalite çalışmalarının sürdürülmesi ve yeni çeşitler geliştirilerek bu çeşitlerin üretim ve kullanım alanlarının artırılması hedeflenmektedir. Öte yandan, 2050 yılında 5 trilyon ABD dolarına ulaşması beklenen dünya bitkisel ilaç pazarından daha fazla pay alabilmek için ham drog ihracatı yerine işlenmiş ürünlerin ihracatına öncelik verilmesi planlanmaktadır.

Anahtar Kelimeler: Türkiye, tıbbi ve aromatik bitkiler, üretim, ticaret. 


\section{INTRODUCTION}

Medicinal and aromatic plants have been used for centuries to provide food, flavor, medicine and healing. For this reason, some plants such as cumin, poppy and anise have been cultivated since prehistoric times. Although more than $40 \%$ of the drugs listed at the beginning of the $20^{\text {th }}$ century were of vegetable origin, this rate was lower than $5 \%$ in the mid-1970s. However, especially after the $1990 \mathrm{~s}$, the new use of medicinal and aromatic plants, the demand for natural products to increase; the volume of use of these plants is increasing every day. Nowadays, it is estimated that the market of medicinal plants has a figure of about 60 billion dollars annually (Zhang, 2013).

Despite the extraordinary developments in the modern medicine, medicine and chemical industry, alternative treatment methods and treatment with medicinal plants are still up-to-date, and even in recent years they have been increasingly interested in developed countries. A population of more than 150 million people in Europe is benefiting from alternative treatment methods. In Germany, which has led the way, people spend 10 billion euros annually on traditional treatment methods; 5 billion of it in his pocket (Anonymous, 2007). On the other hand, close to 2.5 billion people in underdeveloped and developing countries especially low income cannot benefit from known modern medicines and are treated with herbs, especially Traditional Chinese Medicine (TCM), Ayurveda, Tibetan medicine, Unani medicine, Acupuncture, Shaman medicine. (Heide, 1991; Zhang, 2001; 2013).

The aim of this study is to state the current status of medicinal and aromatic plants sector in the world and in Turkey and to suggest needs to be done for the future.

\section{Potential of Medicinal Plants in Turkey and the World}

It is considered that all plant species in the world can be 320,000. 3,000 as a source of food, 25,000 for treatment purposes, 5,000 for industrial purposes, 15,000 as ornamental plants, the rest are used for other purposes. Although there are more unused plants, it is foreseen that as many as 25,000 of them are considered for medicinal purposes and 10,000 as food sources (Anonymous, 2000a).

On the other hand, it is stated that the number of flowering plants in the world is 422,000 and 72,000 of these species are used for medical purposes (Table 1) (Schippmann et al., 2002; 2006). The distribution of plant species on earth is not equal, but also differs in geographical regions of the same generation. The tropical regions are the richest species in terms of species diversity and the number of species decreases as they move towards the poles. The richest species in terms of species are the northern part of South America and the Indonesian archipelago (Anonymous, 2000a; Arslan, 2004; Arslan, 2014; Anonymous, 2019a).

Herbal medicinal products are getting global importance because of their health benefits. There demand is going to increase because of increased interest of consumers in natural products as they are considered safer and more cost effective than synthetic drugs in many cases (Peet, 1999). According to World Health Organization (WHO) about $80 \%$ population of most developing countries like Asia, Africa, Latin America etc. still rely on traditional herbal medicines for their primary health care needs (Bhowmik et al., 2009).

International trade in medicinal plants and their products was US\$ 60 billion in the year 2000, with average annual growth rate of $7 \%$ and was expected to reach US\$ 5 trillion by 2050 (Anonymous, 2000b). China and India are the top exporting countries and Hong Kong, Japan, USA and Germany are the leading importers. Supply of medicinal plants in world is originated from developing countries. Medicinal plant plays a vital role in the health care needs of three quarter of the world's population living in developing countries. Use of medicinal plants is being steadily increased. Pharmaceutical and food industries, traditional or alternative practitioners, folk or household medicine users, cosmetic and flavor industry and many more need these plants (Brandt et al., 2011).

The countries with important medicinal and aromatic plant producers in the world, their production areas and the number of plant species they make cultivation are given in Table 2 . The countries are the largest manufacturers of China and India, it is seen that come after them if Turkey. 
In most European countries, it is observed that medicinal and aromatic plant cultivation is done but the production areas are quite narrow. China and India have been producing medicinal and aromatic plants for many years. In these countries, the main reason for the production of medicinal and aromatic plants in such large areas is the consumption at the same time. On the other hand, it is seen that the number of species produced is quite high as well as the width of the production areas in these two countries. The source of this is the high number of plant species and medicinal plants in these countries.

The number of plant species collected from nature sold in domestic and foreign markets for commercial purposes in Turkey are given as 347 in one study. The number of endemic species among them is 35 . In other words, approximately $11 \%$ of the traded species are endemic. The number of natural plant species collected from nature and sold abroad is about 100. According to the ethnobotany studies conducted in various regions in Turkey, it uses $10-12 \%$ of the natural plant species grown around the local people for various purposes. When all of these are evaluated together, it is estimated that at least 1.000 of the species in Turkey are utilized in various ways and 400 of them are traded (Baytop, 1984; Özhatay et al., 1997; Arslan et al., 2000; Yedek, 2002; Arslan, 2004; Kendir and Güvenç, 2010; Arslan, 2014).

\section{Cultivation and Production of Medicinal Plants in Turkey}

Many medicinal plants, especially aromatic plants, are grown in the fields as single or mixed crops in house gardens and as a small plantation plant. Around 900 medicinal plant species are cultured in the world for commercial purposes (Anonymous, 2019a). This figure corresponds to a ratio of $3.6 \%$ to $1.25 \%$ compared to the number of medicinal plants used above. The production of medicinal plants in Turkey and statistics are given in Table 3. (Anonymous, 2018). Most of the poppy cultivation area with medicinal and aromatic plants in Turkey, cumin, anise and thyme is understood that. The cultivation area of these plants constitutes approximately $90 \%$ of the total cultivation area.
Table 1. Number of total species and medicinal and aromatic plants according to some countries (Schippmann et al., 2006).

Çizelge 1. Bazı ülkelerin toplam tür ve tıbbi ve aromatik bitki sayıs1 (Schippmann et al., 2006)

\begin{tabular}{|c|c|c|c|}
\hline $\begin{array}{l}\text { Countries } \\
\text { Ülkeler }\end{array}$ & $\begin{array}{c}\text { No. of } \\
\text { species } \\
\text { Tür } \\
\text { sayıs1 }\end{array}$ & $\begin{array}{c}\text { No. of } \\
\text { medicinal } \\
\text { and aromatic } \\
\text { plants } \\
\text { Tibbi ve } \\
\text { aromatik } \\
\text { bitki sayıs1 }\end{array}$ & $\begin{array}{c}\text { Ratio of } \\
\text { medicinal } \\
\text { plants (\%) } \\
\text { Tibbi ve } \\
\text { aromatik } \\
\text { bitki oranı } \\
(\%)\end{array}$ \\
\hline China & 32,200 & 4,941 & 15.3 \\
\hline USA & 21,641 & 2,564 & 11.8 \\
\hline India & 18,664 & 3,000 & 16.1 \\
\hline Malaysia & 15,500 & 1,200 & 7.7 \\
\hline Thailand & 11,625 & 1,800 & 15.5 \\
\hline Vietnam & 10,500 & 1,800 & 17.1 \\
\hline Turkey & 10,000 & 3,300 & 33.0 \\
\hline Philippines & 8,931 & 850 & 9.5 \\
\hline Nepal & 6,973 & 900 & 12.9 \\
\hline Pakistan & 4,950 & 1,500 & 30.3 \\
\hline France & 4,630 & 900 & 19.4 \\
\hline Bulgaria & 3,567 & 750 & 21.0 \\
\hline Sri Lanka & 3,314 & 550 & 16.6 \\
\hline Sourh Korea & 2,898 & 1,000 & 34.5 \\
\hline Hungary & 2,214 & 270 & 12.2 \\
\hline Jordan & 2,100 & 363 & 17.3 \\
\hline World & 422,000 & 72,000 & 17.1 \\
\hline
\end{tabular}

Table 2. Medicinal and aromatic plant production areas and plant species in some countries (Kathe et al., 2003).

Çizelge 2. Bazı ülkelerde tıbbi ve aromatik bitki üretim alanı ve üretilen tür sayısı (Kathe et al., 2003).

\begin{tabular}{lcc}
\hline $\begin{array}{l}\text { Countries } \\
\text { Ülkeler }\end{array}$ & $\begin{array}{c}\text { Area (ha) } \\
\text { Uretim alanı } \\
\text { (ha) }\end{array}$ & $\begin{array}{c}\text { No. of } \\
\text { species } \\
\text { Tür say1s1 }\end{array}$ \\
\hline China & 460,000 & 250 \\
India & 300,000 & 150 \\
Turkey & 90,000 & 50 \\
USA & 69,200 & 90 \\
Hungary & 40,000 & 40 \\
Canada & 34,700 & 60 \\
Poland & 30,000 & 30 \\
France & 25,000 & 35 \\
Spain & 19,000 & 40 \\
Romania & 15,000 & 50 \\
Bulgaria & 9,500 & 40 \\
Germany & 5,700 & 45 \\
Austria & 4,300 & 25 \\
Greece & 4,000 & 20 \\
Japan & 3,900 & 35 \\
Croatia & 3,000 & 15 \\
Italy & 2,300 & 25 \\
United Kingdom & 2,000 & 20 \\
Albania & 2,000 & 40 \\
Netherlands & 500 & 20 \\
Bosnia and Herzegovina & 300 & 20 \\
\hline & &
\end{tabular}




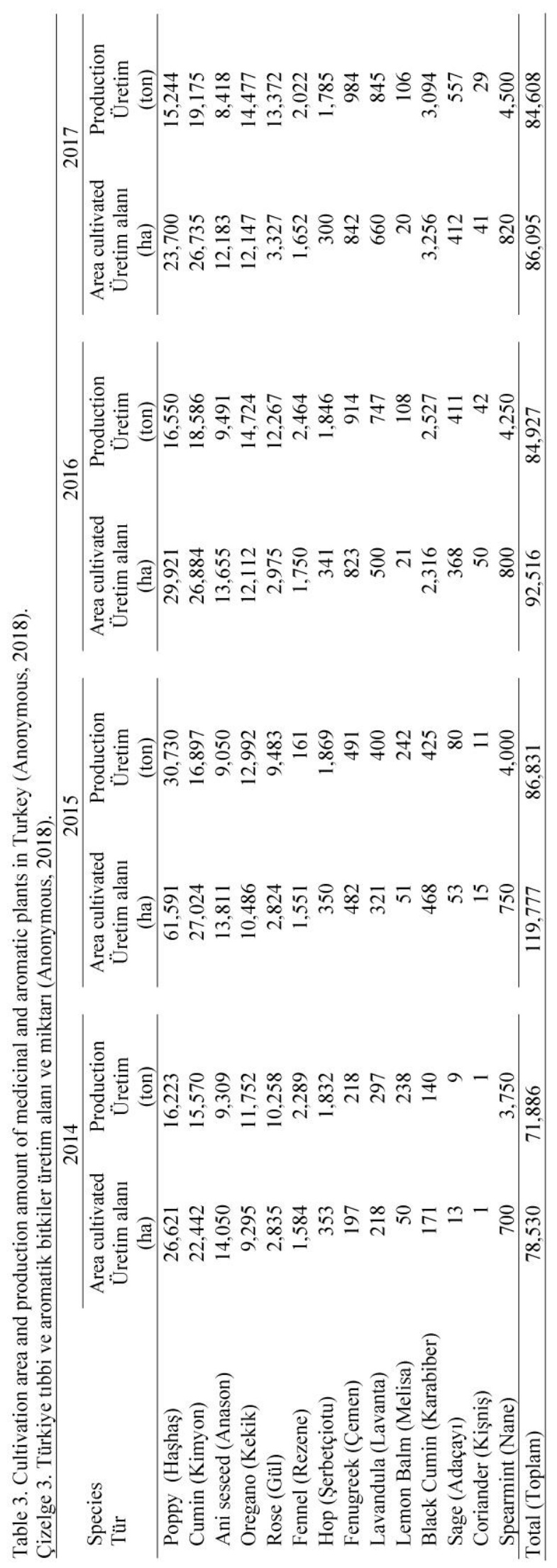


Production and Trade of Medicinal and Aromatic Plants in Turkey

Turkey is carrying out approximately 100 countries worldwide exportation of medicinal and aromatic plants. An important part of its foreign sales is made to North America, European Union, Latin America, Far East and North Africa. US, Germany, Vietnam, Netherlands, Poland, Brazil, Canada, Italy, Belgium, Greece, France and Japan are listed in the list. major pharmaceutical and spice plants thyme exported by Turkey, bay leaf, together with cumin and anise, fennel seeds, juniper bark, mahlep, fenugreek, rosemary, licorice, mint, sumac, sage and lime. The most exported products are oregano and laurel. In 2018, a total of 80 thousand tons of medicinal and aromatic plants were exported and a total of USD 265 million in revenue (Table 4).

Medicinal and aromatic plants which were imported to Turkey in 2018 is given in Table 5. Especially including tea, pepper, anise, oregano, cumin, ginger and carob are main products import to Turkey. However, some of the imported products are processed within the scope of inward processing regime and exported again abroad. Turkey's total medicinal and aromatic plants are just over 38 thousand tons of imports, while its monetary equivalent of just over 79 million dollars. The most important import item in terms of monetary value is green and black tea.

Table 4. Medicinal and aromatic plants exports of Turkey in 2018 (Anonymous, 2019b). Çizelge 4. Türkiye'nin 2018 yılı tıbbi ve aromatik bitkiler ihracatı (Anonymous, 2019b).

\begin{tabular}{lrr}
\hline Product & Amount kg) & Value (US \$) \\
Ürün & Miktar (kg) & Değeri (US \$) \\
\hline Oregano (Kekik) & $16,212,000$ & $52,331,000$ \\
Laurel Leaf (Defne yapră̆1) & $13,253,940$ & $36,716,616$ \\
Cumin (Kimyon) & $6,455,169$ & $19,500,621$ \\
Anis seed (Anason) & $2,418,735$ & $9,637,809$ \\
Sage (Adaçayı) & $1,824,818$ & $6,695,586$ \\
Sumac (Sumak) & $2,108,382$ & $4,491,056$ \\
Licorice (Meyan) & $1,069,961$ & $3,102,837$ \\
Spice Mix (Baharat karışımı) & 300,476 & $2,006,843$ \\
Mahaleb (Mahlep) & 123,283 & $1,242,394$ \\
Spearmint (Nane) & 620,292 & $1,876,792$ \\
Rosemary (Biberiye) & 493,389 & $1,477,264$ \\
Black Cumin (Çörekotu) & 404,691 & 983,074 \\
Carob (Keçi Boynuzu) & $2,421,351$ & $18,433,777$ \\
Linden (Ihlamur) & 116,741 & $1,521,480$ \\
Turmeric (Zerdeçal) & 45,704 & 201,441 \\
Cinnamon (Tarçı) & 38,505 & 234,165 \\
Coriander (Kişniş) & 142,351 & 187,920 \\
Clove (Karanfil) & 5,555 & 99,894 \\
Thyme (Dağ kekiği) & 48,547 & $1,287,456$ \\
Saffron (Safran) & 4,602 & 89,848 \\
Ginger (Zencefil) & 26,368 & 116,984 \\
Curry (Köri) & 24,723 & 78,260 \\
Fenugreek (Çemen) & 168,004 & 298,736 \\
Cardamom (Kakule) & 3,368 & 54,872 \\
Nutmeg (Küçük Hindistan cevizi) & 55,425 \\
Poppy seed (Haşhaş tohumu) & 10,125 & $8,434,688$ \\
Morphine (Morfin) & $25,286,661$ & $265,162,810$ \\
Tea (Çay) & 25,647 & \\
Other Spices (Diğer baharatlar) & $3,321,866$ \\
Total (Toplam) & $2,985,503$ & \\
& $79,960,757$ & \\
\hline
\end{tabular}


Table 5. Medcinal and aromatic plants imports of Turkey in 2018 (Anonymous, 2019b).

Çizelge 5. Türkiye'nin 2018 yılı tıbbi ve aromatik bitkiler ithalatı (Anonymous, 2019b).

\begin{tabular}{lrr}
\hline Product & Amount (kg) & Value (US \$) \\
Ürün & $1,787,584$ & Değeri (US \$) \\
\hline Oregano (Kekik) & 989,611 & $4,750,033$ \\
Laurel Leaf (Defne yapră̆ı) & $1,003,631$ & $1,523,208$ \\
Cumin (Kimyon) & $3,612,533$ & $3,290,609$ \\
Anis seed (Anason) & 743,980 & $6,589,114$ \\
Sage (Adaçayı) & 461,260 & $1,620,684$ \\
Sumac (Sumak) & $1,102,153$ & 113,673 \\
Licorice (Meyan) & 3,374 & $1,985,376$ \\
Spice Mix (Baharat karışımı) & 19,903 & 45,123 \\
Mahaleb (Mahlep) & 87,241 & 92,954 \\
Spearmint (Nane) & 619,752 & 133,100 \\
Rosemary (Biberiye) & $3,678,628$ & 839,080 \\
Black Cumin (Çörekotu) & $2,462,071$ & $7,312,482$ \\
Carob (Keçi boynuzu) & 25,151 & $4,166,059$ \\
Linden (Ihlamur) & 979,376 & 54,442 \\
Turmeric (Zerdeçal) & 873,560 & $1,096,073$ \\
Cinnamon (Tarçı) & 522,207 & $1,542,843$ \\
Coriander (Kişniş) & 279,113 & 275,604 \\
Clove (Karanfil) & 6,276 & 482,837 \\
Thyme (Dağ Kekiği) & 91 & 6,826 \\
Saffron (Safran) & $2,990,512$ & 20,187 \\
Ginger (Zencefil) & 340 & $3,295,411$ \\
Fenugreek (Çemen) & 1,322 \\
Cardamom (Kakule) & 204,675 & 871,164 \\
Nutmeg (Küçük Hindistan cevizi) & 45,820 & 58,087 \\
Poppy seed (Haşhaş tohumu) & 45,950 & 125,069 \\
Morphine (Morfin) & 2 & 368 \\
Tea (Çay) & $15,635,054$ & $38,911,087$ \\
Other Spices (Diğer baharatlar) & 34,633 \\
\hline Total (Toplam) & $38,249,481$ & $79,237,614$ \\
\hline
\end{tabular}

\section{Production and Trade of Essential Oils in Turkey}

Turkey's foreign sales of essential oils for 2018 were approximately $\$ 42$ million. Rose oil, stearopten oil and oregano oil are the main products (Table 6). Increased foreign sales of essential oils in Turkey in recent years, seems to have caused an increase in the number of plant essential oils. Especially in Antalya, Manisa, Mersin, Mugla and Hatay in the province of the plant located in the thyme, laurel, mint, rosemary, cumin, myrtle, lemon leaf, anise and aromatic herbs such as aphids are produced from essential oils. A large part of the export of essential oils is made to EU countries. As of 2018, the main export countries were France, Germany, Madagascar, USA, Switzerland, England, Greece, Ireland, Bahrain, Canada and Spain. The share of France in total export is 53\%. Almost all of the rose oil produced in Turkey is exported. 2018 foreign trade is approximately 14 million dollars. An important part of the export was made to EU countries, USA, Switzerland, Bahrain, Kuwait, Japan, UAE, Australia, Azerbaijan, Turkmenistan, Iraq and Turkey Republic of Northern Cyprus. The share of France in the total foreign oil export was $62 \%$, Germany's share was $13 \%$, the US share was $10 \%$, and Switzerland had a share of $9 \%$.

Essential oils which were imported to Turkey is given in Table 7. Imported essential oils include oregano, orange, lemon, other citrus oils and peppermint oil are the main essential oils imported to Turkey. In 2018, the total amount of imported essential oils was 552 tons and approximately 26 million dollars. 
Improving New Varieties on Medicinal and Aromatic Plants in Turkey

Improving new varieties on medicinal and aromatic plants in Turkey has begun to gain momentum in recent years. It is known that the development of varieties in medicinal and aromatic plants began quite late compared to other cultivated plants. As a result, it is seen that the number of species studied and the number of varieties developed are low. As the cultivation, breeding and cultivar development studies of different species continue, the number of varieties registered will increase over time. Thus, while the number of standard production materials required by different types of manufacturers' increases, the way for standard and quality production will be opened. As a result of breeding and cultivation studies, 55 varieties have been registered so far (Table 8).

Table 6. Essential oil exports of Turkey in 2018 (Anonymous, 2019b).

Çizelge 6. Türkiye'nin 2018 yılı uçucu yağ ihracatı (Anonymous, 2019b).

\begin{tabular}{lrr}
\hline Product & $\begin{array}{c}\text { Amount }(\mathrm{kg}) \\
\text { Urün }\end{array}$ & $\begin{array}{r}\text { Value (US \$) } \\
\text { Değeri (US \$) }\end{array}$ \\
\hline Oregano oil (Kekik yağı) & 65,000 & $5,501,000$ \\
Spearmint oil (Nane yağı) & 16,000 & 168,895 \\
Rosemary oil (Biberiye yağı) & 55 & 5,723 \\
Lavandula oil (Lavanta yağı) & 3,851 & 129,354 \\
Rose oil (Gül yağı) & 16,369 & $14,136,625$ \\
Lemon oil (Limon yağı) & 3,121 & 131,230 \\
Pepermint oil (Tibbi nane yağı) & 1,212 & 44,566 \\
Other citrus oil (Diğer turunçgil yağı) & 4,822 & 113,459 \\
Maceration (Maserasyon) & 280,547 & $6,615,909$ \\
Hydrosol (Hidrosol) & 364,240 & $1,921,192$ \\
Other essential oil (Diğer uçucu yağlar) & 57,922 & $13,754,416$ \\
\hline Total (Toplam) & 813,139 & $42,522,369$ \\
\hline
\end{tabular}

Table 7. Essential oil imports of Turkey in 2018 (Anonymous, 2019b).

Çizelge 7. Türkiye'nin 2018 yılı uçucu yağ ithalatı (Anonymous, 2019b).

\begin{tabular}{lrr}
\hline Product & $\begin{array}{c}\text { Amount }(\mathrm{kg}) \\
\text { Urün }\end{array}$ & $\begin{array}{c}\text { Value (US \$) } \\
\text { Değeri (US \$) }\end{array}$ \\
\hline Oregano oil (Kekik yağı) & 1,790 & $4,864,492$ \\
Spearmint oil (Nane yağı) & 11,985 & 339,135 \\
Rosemary oil (Biberiye yağı) & 1,262 & 63,613 \\
Lavandula oil (Lavanta yağı) & 5,062 & 289,972 \\
Clove oil (Karanfil yağı) & 5,954 & 233,717 \\
Rose oil (Gül yağı) & 380 & $1,996,689$ \\
Orange oil (Portakal yağı) & 243,607 & $3,189,027$ \\
Lemon oil (Limon yağı) & 64,406 & $2,239,109$ \\
Pepermint oil (Tibbi nane yağı) & 55,676 & $1,996,950$ \\
Other citrus oil (Diğer turunçgil yağı) & 31,833 & $2,268,460$ \\
Other essential oil (Diğer uçucu yağlar) & 130,785 & $8,941,328$ \\
\hline Total (Toplam) & 552,740 & $26,422,492$ \\
\hline
\end{tabular}


Table 8. Medicinal and aromatic plant varieties in Turkey (Anonymous, 2019c).

Çizelge 8. Türkiye'deki tıbbi ve aromatik bitki tescilli çeşit sayısı (Anonymous, 2019c).

\begin{tabular}{lc}
\hline Medicinal and aromatic plant varieties & $\begin{array}{c}\text { Number of cultivars } \\
\text { Çeşit sayısı }\end{array}$ \\
Tibbi ve aromatik bitki çeşitleri & 16 \\
Poppy (Haşhaş) & 1 \\
Anise seed (Anason) & 7 \\
Hop (Şerbetçiotu) & 5 \\
Oregano (Kekik) & 4 \\
Sage (Adaçayı) & 1 \\
Thyme (Dağ kekiği) & 2 \\
Fenugreek (Çemen) & 2 \\
Coriander (Kişniş) & 2 \\
Cumin (Kimyon) & 1 \\
Saffron (Safran) & 1 \\
Black cumin (Çörekotu) & 2 \\
Buckwheat (Karabuğday) & 7 \\
Basil (Fesleğen) & 1 \\
Lemon balm (Melisa) & 1 \\
Purple coneflower (Ekinezya) & 1 \\
Mountain tea (Dağçayı) & 1 \\
Golden thistle (Şevketibostan) & 55 \\
\hline Total (Toplam) & \\
\hline
\end{tabular}

\section{CONCLUSION and RECOMMENDATIONS}

In this study the current status of medicinal and aromatic plants sector in the world and in Turkey are discussed. The recommendations are suggested needs to be done for the future are as follow.

1- The increasing demand for medicinal plants creates a great pressure for the plants collected from nature. Training activities should be planned regularly and periodically. A regulation on the collection and trade of medicinal plants should be issued and necessary legal arrangements should be made.

2- Measures should be taken to increase the income level of low income people living in rural areas.

3- Similar studies should be done for the transfer and spice producers in various provinces and the source of the medicinal plants sold (domestic, imported, picking from nature, culture, intended use, shape etc.) should be determined, scientific description of each medicinal plant (genus, species, subspecies / variety, author and family) must be verified and recorded.

4- In order to reduce the pressure on our natural plants, the studies should be initiated to cultivate as many plants as possible, especially the plants that are exported and used in Turkey, and the production of those who are successful should be expanded.

5- The cultivation of medicinal plants should be considered in good agricultural practices for spices and/or organic farming developed for these plants. Importance should be given to organic certification.

6- Medicinal-aromatic and bulbous tuberous plants should be supported.

7- After harvesting, there will be a minimum product loss and after-harvest operations should be carried out in a timely manner and in accordance with the technique.

8- Cultivated or newly purchased medicinal plant species must have the characteristics that are in the pharmacopoeia of that country or the recipient countries and spice plants must meet the required specifications. Consideration should be given to the improvement and treatment of medicinal aromatic plants.

9- Considering that in Turkey has different climates and geographical regions, adaptation studies of plants grown in other countries or 
collected from the nature of that country should be carried out.

10- In addition to the export of medicinal aromatic plants as raw drugs, the production and export of processed intermediate or end products should be encouraged and the necessary support should be provided.

11- The use of medicinal plants is commonly standardized extracts in the world. In Turkey, herbal medicines and food supplements for domestic firms producing raw materials they use as a large portion of the extract almost all of America, Germany and China they provide. Depending on the increase in domestic production in the extract, our dependence on foreign sources will gradually decrease.

12- In the chemical analysis of medicinal plants, studies to be carried out to convert the newly found compounds into drugs should be supported and the methods of evaluation of the substances with known efficacy should be investigated.

13- To standardize through pharmacopoeia, codex and other legal documents to ensure the safety and efficacy of medicinal plants; new standard methods suitable for evaluating the pharmacology of medicinal plants should be developed.

\section{REFERENCES}

Anonymous. 2000a. Welt in Wandel: Erhaltung und Nachhaltige Nutzun der Biosphaere, Jahresgutachten 1999. Springer. Berlin XXVI+483s.

Anonymous. 2000b. Medicinal Plants Introduction, Indian System of Medicine and Homoeopathy (ISMH), Department of ISMH, Ministry of Health and Family Welfare, Govt. of India. Available at: http:// indianmedicine.nic.in/html/plants/mimain.htm.

Anonymous. 2007. Schul-und UND Komplentaermedizin Miteinander statt nebeneinander Dtsch Arztebl. 104 (46) A 3148.

Anonymous. 2018. TUIK. Cultivation area and production values of medicinal and aromatic plants of Turkey. www.tuik.gov.tr. Erişim: 15.10.2018.
14- In the production of medicinal aromatic plants, the farmer should warn the farmer about the speculation made in his / her use; those who do this should be warned and punished.

15- Regular records should be kept from collection and / or production to export of medicinal and aromatic plants. In order to carry out healthy studies on these plants, it is necessary to monitor their trade, export and especially production amounts and how much of them are collected from nature and how much of it comes from field production in the statistics. This issue is important all over the world.

16- Treatment of medicinal aromatic plants, cleaning, relocation, classification and residual residues after obtaining the essential oil should be evaluated and the costs should be reduced and new products should be obtained. Examples of spices processing plants such as oil from volatile carriers, aniseed, cumin, as well as essential oils of seeds as well as the evaluation of fixed oils of the seeds.

Anonymous. 2019a. Der Internationale Standard für die nachhaltige Wildsammlung von Heilpflanzen (ISSCMAP). http://www.floraweb.de/map-pro/. Erișim: 02.03.2019.

Anonymous. 2019b. TUIK Essential oil import and export values of Turkey. www.tuik.gov.tr. Erişim: 14.02.2019.

Anonymous. 2019c. Milli Çeşit Listesi (Tarla Bitkileri / Field Crops) Tohumluk Tescil ve Sertifikasyon Merkezi Müdürlüğü. https://www.tarimorman.gov.tr/BUGEM/ TTSM/ Sayfalar/Detay. aspx?SayfaId=85. Erişim: 10.09.2019.

Arslan, N. 2004. Cultivation of natural plants. Turkish Agriculture Magazine 155: 26-31.

Arslan, N. 2014. Our Endemic Medicinal Plants. 2. Medical Aromatic Plants Symposium. Invited Paper. September 23-25 2014. Yalova. 
Arslan, N., B. Gürbüz, and S. Özcan. 2000. Use and trafficking of native plants in Turkey. Ekin D. 12: 98102

Baytop, T. 1984. Treatment with plants in Turkey. Istanbul Univ. Faculty of Pharmacy Publications.

Bhowmik, D., K. P. Sampath Kumar, P. Tripathi, and B. Chiranjib 2009. Traditional herbal medicines: An overview. Archives of Applied Science Research 1: (2) $165-177$

Brandt, F. S., A. Cazzaniga, and M. Hann. 2011. Cosmeceuticals: Current Trends and market analysis. Seminar in Cutaneous Medicine and Surgery 30 (3): 141-143.

Heide, L. 1991. Traditionelle Arzneipflanzen in der Gesundheitsversorgung der Dritten Welt: Möglichkeiten und Grenzen. Zeitschrift für Phytotherapie 12: 1-8.

Kathe, W., S. Honnef, and A. Heym. 2003. Medicinal and Aromatic Plants in Albania, Bosnia Herzegovina, Bulgaria, Croatia and Romania: a study of the collection of and trade of medicinal and aromatic plants (MAPs), relevant legislation and the potential of MAP us efor financing natüre conservation and protected areas. BfN skrioten 91. Bonn, Germany.

Kendir, G., and A. Güvenç. 2010. Ethnobotany and an overview of the ethnobotanical study conducted in Turkey. Hacettepe Uni. Faculty of Pharmacy 30 (1): 49-80.

Özhatay, N., M. Koyuncu, S. Atay, and A. Byfield. 1997. About Turkey's natural trade of medicinal plants Study, Wildlife Conservation Society, Istanbul.
Peet, M. 1999. Consumers Expectations and Successful Functional Ingredients, in Functional Foods and Practical and Scientific Considerations of Conducting Food Efficacy Trials to Support Health Claims, International Business Communication (IBC) Library Series, London, UK.

Schippmann, U., D. J. Leaman, and A. B. Cunningham. 2002. Impact of Cultivation and Gathering of Medicinal Plants on Biodiversity: Global Trends and Issues. Biodiversity and the Ecosystem Approach in Agriculture. Proc. 9 session of the Commission on Genetic Resources for Food and Agriculture. Oct. 1213, 2002. FAO, Rome. ftp://ftp.fao.org/docrep/ fao/005/aa010e/AA010E00.pdf.

Schippmann, U., D. J. Leaman, and A. B. Cunningham. 2006. A Comparison of Cultivation and Wild Collection of Medicinal and Aromatic Plants Under Sustainability Aspects. p. 75-95. In: R.J. Bogers, L.E. Craker, and D. Lange (eds.), Medicinal and Aromatic Plants. Proc. Frontis Workshop on Medicinal and Aromatic Plants, Wageningen, The Netherlands, 17-20, April 2005. Nucleus for Strategic Expertise Wageningen University and Research Centre, Wageningen.

Yedek, K. 2002. Medicinal Plants for Sale in Istanbul, A. Ü. Graduate School of Natural and Applied Sciences, Ankara.

Zhang, X. 2001. WHO Legal Status of Traditional Medicine and Complementary/ Alternative Medicine: A Worldwide Review Geneva.

Zhang, X. 2013. WHO Traditional Medicine Strategy: 20142023. Geneva. 